\title{
Determinants of Regional Innovation in Russia: Are People or Capital More Important?
}

\author{
Stepan Zemtsov \\ Senior Research Fellow, IAER RANEPA*. E-mail: zemtsov@ranepa.ru
}

Alexander Muradov

Graduate Student, Department of conceptual analysis and planning, MIPT**. E-mail: muradoz@yandex.ru

\section{Imogen Wade}

Research Fellow, ISSEK HSE**; and PhD Candidate, University College London. E-mail: imogen.wade.10@ucl.ac.uk

\section{Vera Barinova}

Head of Laboratory for research on corporate strategies and firm behaviour, IAER RANEPA

E-mail: barinova-va@ranepa.ru

\begin{abstract}
${ }^{*}$ IAER RANEPA - Institute of Applied Economic Research, Russian Presidential Academy of National Economy and Public Administration under the President of the Russian Federation (RANEPA). Address: 82/1 Vernadsky ave., 119571 Moscow, Russian Federation

${ }^{*}$ MIPT - Moscow Institute of Physics and Technology State University. Address: 9 Institutsky per., 141700

Dolgoprudny, Moscow oblast, Russian Federation

*** ISSEK HSE - Institute for Statistical Studies and Economics of Knowledge, National Research University Higher School of Economics. Address: 20 Myasnitskaya str., 101000 Moscow, Russian Federation
\end{abstract}

\begin{abstract}
S pending on innovation increased annually in the 2000 s in Russia's regions, but innovation productivity varies greatly between regions. In the current climate of sanctions between Russia and Western countries and limitations on international technology transfer, there is a growing need to analyse the factors influencing regional innovation. Previous empirical studies using a knowledge production function approach have found that the main factor of growth in regional innovation is increasing spending on research and development (R\&D).

Our econometric analyses show that the quality of human capital, a product of the number of economically

active urban citizens with a higher education (the so-called creative class) has the greatest influence on the number of potentially commercializable patents.

Other significant factors were buying equipment, which indicates a high rate of wear and tear of Russian machinery, and spending on basic research. The 'centre-periphery' structure of Russia's innovation system favours the migration of highly qualified researchers to leading regions, which weakens the potential of the 'donor regions. However, at the same time, we see significantly fewer limitations on knowledge spillovers in the form of patents and - in this case - proximity to the 'centres' is a positive factor.
\end{abstract}

Keywords: patenting level; human capital; knowledge spillovers; regions of the Russian Federation; knowledge production function; R\&D; creative class

DOI: $10.17323 / 1995-459 X .2016 .2 .29 .42$
Citation: Zemtsov S., Muradov A., Wade I., Barinova V. (2016) Determinants of Regional Innovation in Russia: Are People or Capital More Important? Foresight and STI Governance, vol. 10, no 2, pp. 29-42.

DOI: 10.17323/1995-459X.2016.2.29.42 
$\mathrm{T}$ The economic crisis in Russia and its aftermath led to a significant fall in the rate of growth. In such circumstances, diversification of the Russian economy is required, including significant changes in manufacturing processes and the creation of new products [Gokhberg, Kuznetsova, 2010; 2011]. Borrowing new technologies is limited in the current climate of sanctions between Russia and Western countries, so studying the factors determining innovation becomes more relevant and necessary. To date, Russia has created a significant number of support instruments for innovation and the necessary infrastructure in the majority of regions [Barinova et al., 2014]. Spending on innovation has increased year on year, and yet we see a strong divergence between regions in terms of results. A common, yet often criticized, indicator of innovation is the number of registered intellectual property (IP): patents, utility models, industrial prototypes, etc. Patents have been used as an indicator of IP for many decades [Griliches, 1979, 2007]. Yet although patents can be considered a result of inventions, not all patents will be commercialized and become an innovative product or process.

Initially, the need for a regional analysis of innovation was disputed and there are still debates about which territorial level is preferable to study when looking at innovation [Brenner, Broekel, 2009]. The need to study regional factors of innovation is justified by ideas about knowledge spillovers and tacit knowledge. By this, we mean the particularities of different types of knowledge, the opportunity to use knowledge an infinite number of times, and limited chances to stop other agents from using this knowledge. Thus, innovation by one agent leads to positive, spillover effects for others, i.e., knowledge spillovers [Acs et al., 2009; Feldman, 1999; Meissner, 2012; Pilyasov, 2012; Dettmann et al., 2014]. ${ }^{1}$ Besides, tacit knowledge cannot be fully formalized and is transferred 'from teacher to student' [Polanyi, 1966]. Localization and creation of knowledge occur on both local and regional levels.

In this paper, we aim to assess the main factors of innovation at a regional level in Russia between 1998 and 2011 using official regional statistics and datasets of the Organization for Economic Cooperation and Development (the OECD). Data on patents, as with all statistics on innovation in Russia, are not always reliable [Bortnik et al., 2013; Baburin, Zemtsov, 2013]. Hence, our first hypothesis is:

H1: innovation activity in Russia is hard to model econometrically.

Second, we hypothesize that human capital is a more important factor affecting innovation in Russia than R\&D spending because of the ineffectiveness of R\&D funding. However, in the 2000s the significance of human capital declined because of researchers' increasing average age [HSE, 2014] and the decline in the quality of education. Thus:

H2: Human capital is more important as a factor affecting innovation in Russia than R\&D spending because of the ineffectiveness of Rer funding.

Third, we investigate the relationship between inter-regional (i.e. between sub-national regions) knowledge transfer and innovation. Thus we posit that:

H3: Inter-regional knowledge transfer in Russia has a positive effect on innovation.

\section{Literature review and conceptual framework of the study}

In the present study, we use the model of the knowledge production function (KPF). The KPF model describes the linkages between R\&D spending, human capital, and innovation output. The KPF was first developed by Paul Romer, Zvi Griliches, and Adam Jaffe in the late 1980s. According to [Romer, 1986], new knowledge is produced as a result of using concentrated human capital $H$ and the existing stock of knowledge $A$. The resulting new knowledge takes the form of new technologies:

$$
d A / d t=\delta H^{v} \times A^{s},
$$

where $\delta$ is the coefficient of the productivity $\mathrm{H}$, and $v$ and $s$ are the empirical coefficients.

The coefficient $s$ is positive if the knowledge generated from previous research increases the productivity of the research sector

Romer's model theoretically sets out the influence of endogenous factors on economic growth, although several of its assumptions (for example, innovation only occurs in the R\&D sector, and identifying total factor productivity, TFP, only with innovation) are not supported by empirical evidence.

Griliches defined a knowledge production function based on a simple model of 'inputs-outputs' [Griliches, 1984]. He showed that R\&D expenditures influence the production of certain unobservable knowledge that has economic value. Yet only some of this knowledge can be identified and measured. Besides, a significant amount of knowledge determines TFP, and hence cannot be identified with TFP. Griliches measures innovation output as patents:

$$
\text { Patent }=f\left(R n D_{-} \exp \right),
$$

where:

Patent is the number of patents;

RnD_exp - spending on R\&D.

\footnotetext{
${ }^{1}$ Knowledge spillovers refer to a process when knowledge created by one firm or organization can be used by another entity without the need for compensation, or for a payment less than the value of the knowledge itself [Pilyasov, 2012].
} 
Griliches pointed out that both current and historical spending on R\&D influence knowledge accumulation. The process of doing research and development is protracted and includes the acquisition, adaptation, and use of production factors. Indeed, much literature in innovation studies emphasize the cumulative effect of R\&D spending in previous periods of time. Another determinant of the process of raising the technological level in a given economic sector is the positive externalities from knowledge in other sectors i.e. knowledge transfer.

An expanded version of the KPF model includes human capital either operationalized as the number of years of education or the number of employed in R\&D. In this paper, we use this expanded version with Romer's specification (equation 1 above). In this case, innovation depends on the number of R\&D employees and R\&D expenditure. ${ }^{2}$

Many empirical studies have used a KPF approach. The majority of these studies find that R\&D spending, knowledge spillovers, the level of economic diversification, and human capital have significant effects on innovation output (Table 1).

Brenner and Broekel suggest an alternative model that departs from the main assumptions of the KPF approach [Brenner, Broekel, 2009]. Their critique of the knowledge production function is that innovation processes are clearly probabilistic in nature, in contrast to deterministic production processes. Knowledge - used to create innovation - never decreases, contrary to the supply of natural resources. They underline that a region is not an innovator by itself but rather part of a regional community of separate individuals that participates in innovation processes. It is impossible to generate more innovation only by increasing funding and hiring new researchers because innovation processes are, to a large extent, cumulative and involve much tacit knowledge. Thus, a long time is needed for sufficient scientific information, knowledge, and skills to accumulate and enable a sustainable, innovation-generating centre to form in a given location. With time, the corresponding institutional structures that can store, absorb, transfer, and reproduce knowledge and competencies will be created (e.g. universities). Moreover, given sufficient time research centres will be able to take root in the region. All these institutions help in producing knowledge spillovers, although the presence of institutional and cross-disciplinary barriers reduce any possible positive externalities and spillovers of knowledge. Brenner and Broekel's alternative model highlights the key role of human capital, entrepreneurial spirit, and related traits for innovation.

\section{Table 1. Summary of key empirical studies examining the factors of innovation}

\begin{tabular}{|c|c|c|c|c|c|c|c|}
\hline 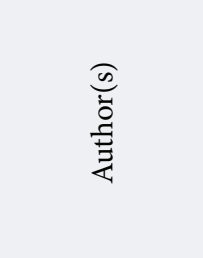 & 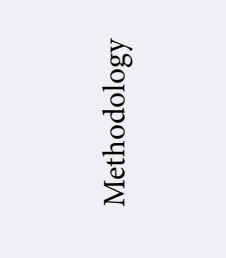 & 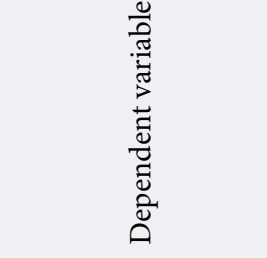 & 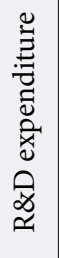 & 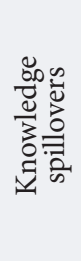 & 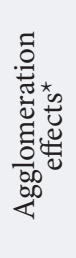 & 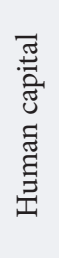 & 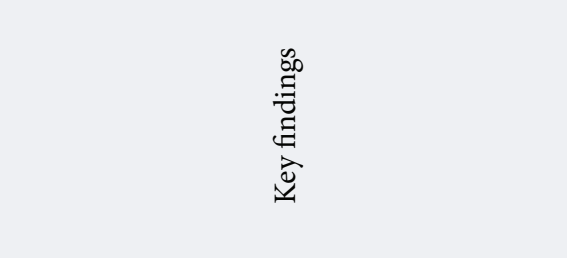 \\
\hline [Jaffe, 1989] & $\begin{array}{l}\text { Panel regression } \\
\text { with fixed } \\
\text { effects }\end{array}$ & $\begin{array}{l}\text { Number of } \\
\text { applications for } \\
\text { national patents }\end{array}$ & + & + & & & $\begin{array}{l}\text { Key influence of R\&D spending, positive } \\
\text { influence of co-location of state and private } \\
\text { research centres (knowledge spillovers) }\end{array}$ \\
\hline $\begin{array}{l}\text { Feldman, } \\
\text { Florida, 1994] }\end{array}$ & Least squares & New production & + & + & + & & $\begin{array}{l}\text { Significant and positive influence of private } \\
\text { and state R\&D co-financing }\end{array}$ \\
\hline $\begin{array}{l}\text { [Bottazzi, Peri, } \\
\text { 2003] }\end{array}$ & $\begin{array}{l}\text { Panel regression } \\
\text { with fixed } \\
\text { effects }\end{array}$ & $\begin{array}{l}\text { Number of national } \\
\text { patents per one } \\
\text { R\&D employee }\end{array}$ & + & + & + & & $\begin{array}{l}\text { Influence of R\&D spending of neighbouring } \\
\text { regions sharply decrease if the distance } \\
\text { between regions exceeds } 300 \mathrm{~km}\end{array}$ \\
\hline $\begin{array}{l}{[\text { Shterzer, }} \\
2005]\end{array}$ & $\begin{array}{l}\text { Panel regression } \\
\text { with fixed } \\
\text { effects }\end{array}$ & $\begin{array}{l}\text { Number of } \\
\text { applications for } \\
\text { national patents }\end{array}$ & + & & + & - & $\begin{array}{l}\text { Positive impact of research funding, and } \\
\text { negative impact of potential knowledge } \\
\text { spillovers }\end{array}$ \\
\hline $\begin{array}{l}\text { [Leslie, } \\
\text { O'hUallachain, } \\
\text { 2007] }\end{array}$ & Least squares & $\begin{array}{l}\text { Number of } \\
\text { commercialized } \\
\text { patents }\end{array}$ & + & + & + & + & $\begin{array}{l}\text { Greater role of region's structural indicators } \\
\text { and human capital on innovation output } \\
\text { compared to R\&D spending }\end{array}$ \\
\hline [Suslov, 2007] & $\begin{array}{l}\text { Panel regression } \\
\text { with fixed } \\
\text { effects }\end{array}$ & $\begin{array}{l}\text { Share of innovative } \\
\text { enterprises }\end{array}$ & & - & & + & $\begin{array}{l}\text { Number of researchers has significant effect } \\
\text { on regions' patenting activity }\end{array}$ \\
\hline $\begin{array}{l}\text { [Mariev, Savin, } \\
\text { 2010] }\end{array}$ & $\begin{array}{l}\text { System GMM } \\
\text { estimation }\end{array}$ & $\begin{array}{l}\text { Volume of } \\
\text { innovative } \\
\text { production }\end{array}$ & + & - & & & $\begin{array}{l}\text { Positive impact of FDI on innovation } \\
\text { activity and tendency for innovation to be } \\
\text { concentrated in certain regions }\end{array}$ \\
\hline $\begin{array}{l}{[\text { Archipova, }} \\
\text { Karpov, 2012] }\end{array}$ & $\begin{array}{l}\text { System of } \\
\text { simultaneous } \\
\text { equations }\end{array}$ & $\begin{array}{l}\text { Number of } \\
\text { patents and share } \\
\text { of innovative } \\
\text { enterprises }\end{array}$ & + & + & & & $\begin{array}{l}\text { Significant relationship between patenting } \\
\text { and innovative activity, and significance of } \\
\text { applied research funding }\end{array}$ \\
\hline $\begin{array}{l}{[\text { Crescenzi, }} \\
\text { Jaax, 2015] }\end{array}$ & $\begin{array}{l}\text { Panel regression } \\
\text { with fixed } \\
\text { effects }\end{array}$ & $\begin{array}{l}\text { Number of } \\
\text { applications for } \\
\text { PCT patents }\end{array}$ & + & + & + & + & $\begin{array}{l}\text { R\&D spending in neighbouring regions } \\
\text { has significant effect on regions patenting } \\
\text { activity }\end{array}$ \\
\hline
\end{tabular}

${ }^{2}$ Empirical models use either the first or the second variable, not both as they are often strongly correlated with each other [Fritsch, Franke, 2003]. 


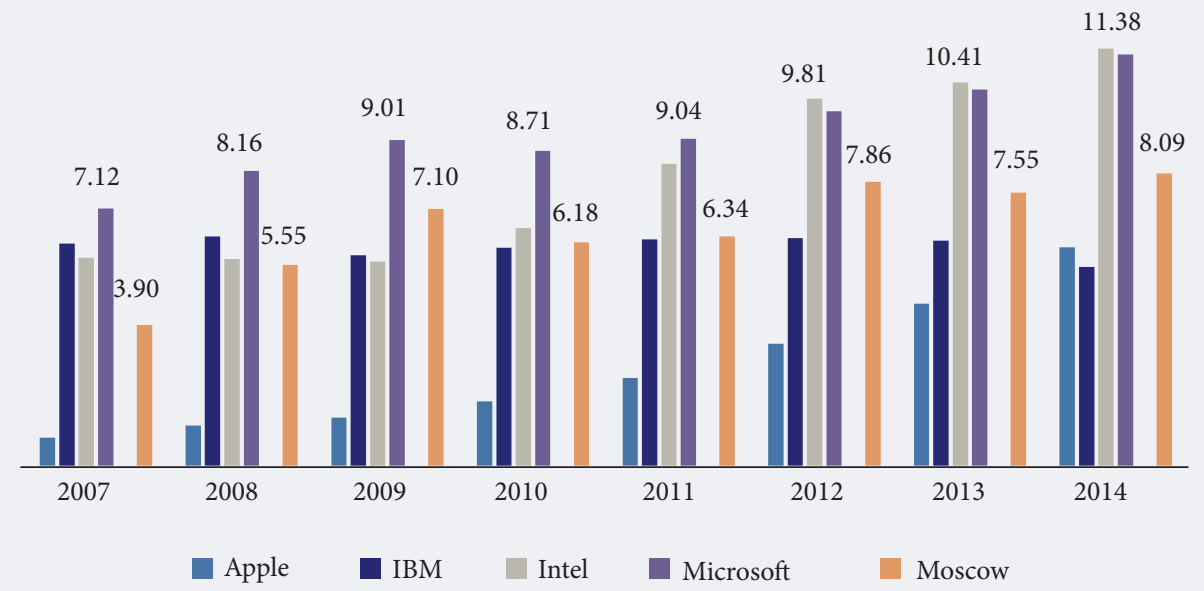

Source: compiled by the authors based on data available on the website Statista.com. Availavle at: www.statista.com, accessed 17.06.2015.

\section{Data and methodology}

Empirical studies from a variety of countries have found a positive influence of private investment on innovation output. The largest technological firms (such as Apple, Samsung, and Google) invest heavily in $\mathrm{R} \& \mathrm{D}$, have their own R\&D divisions, run joint research projects, and support start-ups. Figure 1 below shows that even Russia’s biggest patent producer (Moscow city) spends far less on R\&D than many of these multinationals.

Meanwhile, the largest companies in Russia are primarily active in extracting natural resources, thus their R\&D input is significantly lower. At the same time, the lion's share of patents belongs to research organizations and individuals. This indicates the weak state of the market for innovation and the low demand for advanced technologies from state bodies, and state-owned and private firms.

On average, Russian regions have a low share of commercialized patents; in the $2000 \mathrm{~s}$, this share did not exceed 7\% [NBK--group, 2013]. A indicator of the low quality of patents in Russia's regions is the high volatility in the number of patent applications over time and the excessively high number of patents per capita in some regions. For example, Ivanovo region saw its number of patent filings increase by about 13 times in just two years from 2006 to $2008^{3}$ without any corresponding increase in R\&D funding or numbers of researchers [Baburin, Zemtsov, 2013]. In other regions of Russia, patent activity is very low and is likely random in nature.

Using PCT-applications data (Patent Cooperation Treaty) can give more reliable information about the level and quality of inventive activity. PCT patents protect the rights of inventors in the territory of countries that have signed up to the Paris Convention. Applying for a PCT patent is generally considered much harder than for a Russian or domestic patent because the verification process and registration of the patent can take several years. The costs at different stages of the checking process can add up to USD 3000. Despite the fact that PCT patents have greater potential to be commercialized, ${ }^{4}$ a significant drawback of using PCT-Patent statistics is the very low levels of PCT patenting in most Russian regions. In this paper, we carry out a series of regression analyses to identify the determinants of regional innovation activity. We use panel data from 67 regions of the Russian Federation in the period from 1998 to 2011. The source of these data is the official statistical handbooks entitled 'Russian Regions: social and economic indicators' ${ }^{5}$ as well as datasets of the OECD (Table 2). We excluded regions from our sample where the variation coefficients for the number of granted patents was more than 0.4 because this indicates unstable patenting activity. We assumed that if the dynamics of patenting in the region during the 2000s dramatically changed, these shifts were likely caused by errors in statistical accounting of regional patent offices. In reality, it is virtually impossible to hugely increase the number of patent applications in a region in a single year without an accompanying rise in R\&D spending and researcher numbers. Hence we excluded these regions from our analysis.

\footnotetext{
${ }^{3}$ A search of the patent database using Google Scholar revealed that thousands of applications were registered (the majority by teams of inventors) by Professor Yulia Schepochkina of Ivanovo State Polytechnic University (Available at: https://scholar.google. $\mathrm{ru} / \mathrm{scholar}$ ?as_vis $=1 \& \mathrm{q}=$ ю.а.+щепочкина\&hl=ru\&as_sdt=0,5, accessed 30.04.2015). Some of the most significant inventions include: 'A method to produce composites for preparing drinks' (RF №2497416), 'Flying apparatus' (RF №2387574), and 'Billiard ball' (RF №2546478).

${ }^{4}$ Some studies show that the quality of PCT patents is sometimes questionable For example, the Chinese state actively encourages patenting and it is a criterion for giving employees salary raises and for career promotions [Lei et al., 2012].

${ }^{5}$ Available at: http://www.gks.ru/wps/wcm/connect/rosstat_main/rosstat/ru/statistics/publications/catalog/doc_1138623506156, accessed 12.09.2015.
} 
Because of our concerns about the reliability of Russian patent data and their inconsistencies with innovation regionally, we developed a new indicator reflecting the number of potentially commercializable patents (Innov) (Figure 2):

$$
\text { Innov }=0.08 \times \text { Pat_rus }+0.5 \times P C T,
$$

Where:

Pat_rus is the number of submitted patent applications registered by agencies of the Federal Service for Intellectual Property (Rospatent);

PCT - the number of submitted PCT patent applications.

The coefficients here reflect the rate of commercialization for each type of patents. For Russian patents, the average coefficient rate does not exceed $8 \%$, while for PCT patents it is about $50 \%$ on average. ${ }^{6}$ The disadvantage of this approach is that it assumes all regions have the same commercialization rates. It is clear that this is far from reality but there are no accessible and accurate patent commercialization data disaggregated to the regional level in Russia. The majority of innovations are generated in the largest regional research centres. The Innov indicator over the time period examined had a positive trend in the majority of Russia's regions. Figure 3 shows nominal R\&D expenditures by region relative to gross regional product $(\mathrm{GRP})()$ in 1998 prices:

, $R n D \_a n y_{t}^{*}=\frac{R n D \_a n y_{t}}{Y_{t}} \times Y_{1998} \times \prod_{i=1998}^{t-1} p h c_{i}$,

Where:

Rnd_any ${ }_{t}$ - real internal spending in 1998 prices on all types of R\&D for the period $t$;

$R n d \_$_any ${ }_{t}-$ nominal spending on all types of R\&D in the period $t$;

$Y_{1998}$ - gross regional product at the end of 1998;

$Y_{t} 1998$ GRP over the period $t$;

$p h c_{t}$ - index of the volume for the period $t$ relative to the previous year.

Internal current spending on basic research are actual expenditures expressed in monetary form for experimental or theoretical research that aims to produce new knowledge without any mention of possible future applications of this resulting knowledge. Applied research seeks ways to use the results from basic research, and methods to address specific, existing problems. Given their largely academic nature, we expect basic and applied research to have less influence on our dependent variable than spending on development. The latter is systematic work based on cumulative knowledge (both basic and applied) that strives to create new products, services, processes, and systems, or improve existing ones. We calculated spending based on statistical reporting carried out by individual organizations in the reporting year.

Most existing studies operationalize human capital as the number of R\&D staff. This indicator represents the number of employees doing work that accumulates and systematically increases the total volume

\begin{tabular}{|c|c|c|}
\hline Indicator & Description & $\begin{array}{c}\text { Expected impact } \\
\text { on innovation }\end{array}$ \\
\hline \multicolumn{3}{|c|}{ Current R\&D expenditures in 1998 prices (equation 4 ) } \\
\hline Rnd_exp & Total current R\&D expenditures (million roubles) & + \\
\hline \multicolumn{3}{|c|}{ By type of expenditures } \\
\hline Rnd_infra & Current expenses on acquisition of equipment (million roubles) & + \\
\hline Rnd_salary & Current expenses on researchers' salaries (million roubles) & + \\
\hline \multicolumn{3}{|c|}{ By type of work } \\
\hline RnD_basic & Current expenses on basic research (million roubles) & \pm 0 \\
\hline Rnd_appl & Current expenses on applied research (million roubles) & \pm 0 \\
\hline RnD_dev & Current expenses on developmental research (million roubles) & + \\
\hline \multicolumn{3}{|c|}{ Human capital (equation 5) } \\
\hline HC_urb & Number of economically active urban residents with a higher education (thousand people) & + \\
\hline RnD_empl & Number of R\&D researchers (people) & + \\
\hline \multicolumn{3}{|c|}{ Agglomeration effects } \\
\hline Pop_density & Population density & + \\
\hline Urban & Share of urban inhabitants (\%) & + \\
\hline \multicolumn{3}{|c|}{ Knowledge spillovers } \\
\hline Know_spill & Potential for interactions between researchers from different regions of Russia (equation 6) & + \\
\hline Neigh_innov & Level of average patenting activity in neighbouring regions & + \\
\hline
\end{tabular}

\footnotetext{
${ }^{6}$ Based on the PCT Yearly Review 2013 [WIPO, 2013], about half of all submitted patent applications are granted. The resulting commercialization of PCT patents is close to $100 \%$.
} 


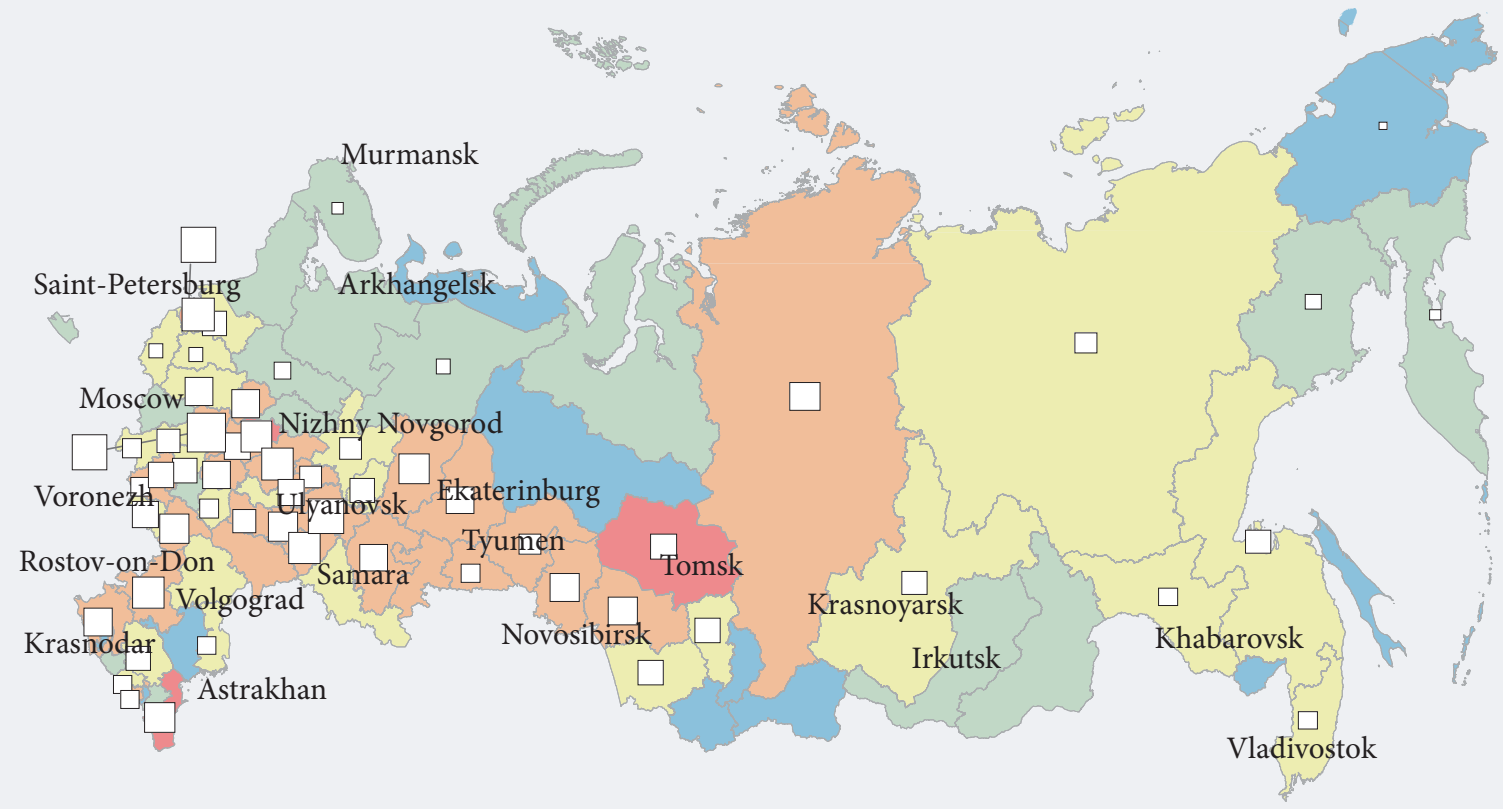

Number of potentially commercialized patents per million economically active urban citizens

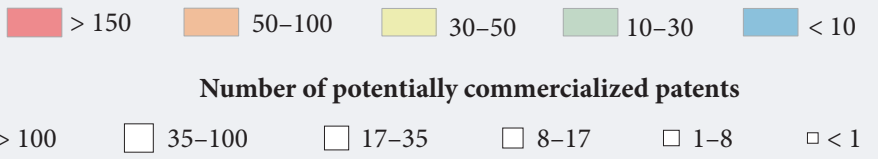

Source: compiled by the authors.

of scientific knowledge. However, in today's innovation systems, professional researchers are not the only people creating new technologies. Hence, we chose to develop a new indicator of human capital that represents the number of economically active urban residents with a higher education $\left(H C \_u r b\right)^{7}$ (Figure 4). We calculate this indicator using the following equation:

$$
H C \_u r b=E c o n \_A c t \times U r b a n \times H i g h \_e m p l,
$$

Where:

Econ_Act - the number of economically active population (thousand people);

Urban - the share of urban population (\%);

High _ empl — the proportion of employees with a higher education (\%).

The main advantage of this new indicator is that it factors in all potential innovators. These are people who have sufficient knowledge to carry out systematic research when there are well-developed infrastructures. The indicator does, however, tend to understate the level of human capital in less urbanized regions, and overestimate it in the innovation-leading regions. This may be because of the links between the indicator's components: for example, a large proportion of employees with a higher education is closely correlated with a greater share of the urban population. However, we argue that this limitation is not very significant because the heterogeneity unaccounted for in the indicator only acts on the outcome measure in one direction and does not lead to the crowding together of regions. We also employ another indicator of human capital to assess regional innovation: the number of economically active urban residents, calculated as per equation (5) without the factor High _ empl.

To measure potential knowledge spillovers related to interactions between researchers from different regions, we developed the indicator Know_spill, based on gravity models: ${ }^{8}$

$$
\text { Know_spill }_{i}=\sum_{j} \frac{\sqrt{R n D \_e m p l_{i} \times R n D_{-} e m p l_{j}}}{R_{i j}^{\alpha}},
$$

\footnotetext{
7 The creative class as defined broadly [Florida, 2002] is what Zubarevitch calls residents of the 'first Russia' [Zubarevitch, 2010, 2013]. This is where human capital is concentrated.

${ }^{8}$ It is assumed that there is an inverse dependence between the potential interactions and distance between regions. Examples of calculating market potential using gravity models can be found in [Hanson, 2005; Head, Mayer, 2004].
} 


\section{Figure 3. R\&D spending in regions of Russia, 2012}

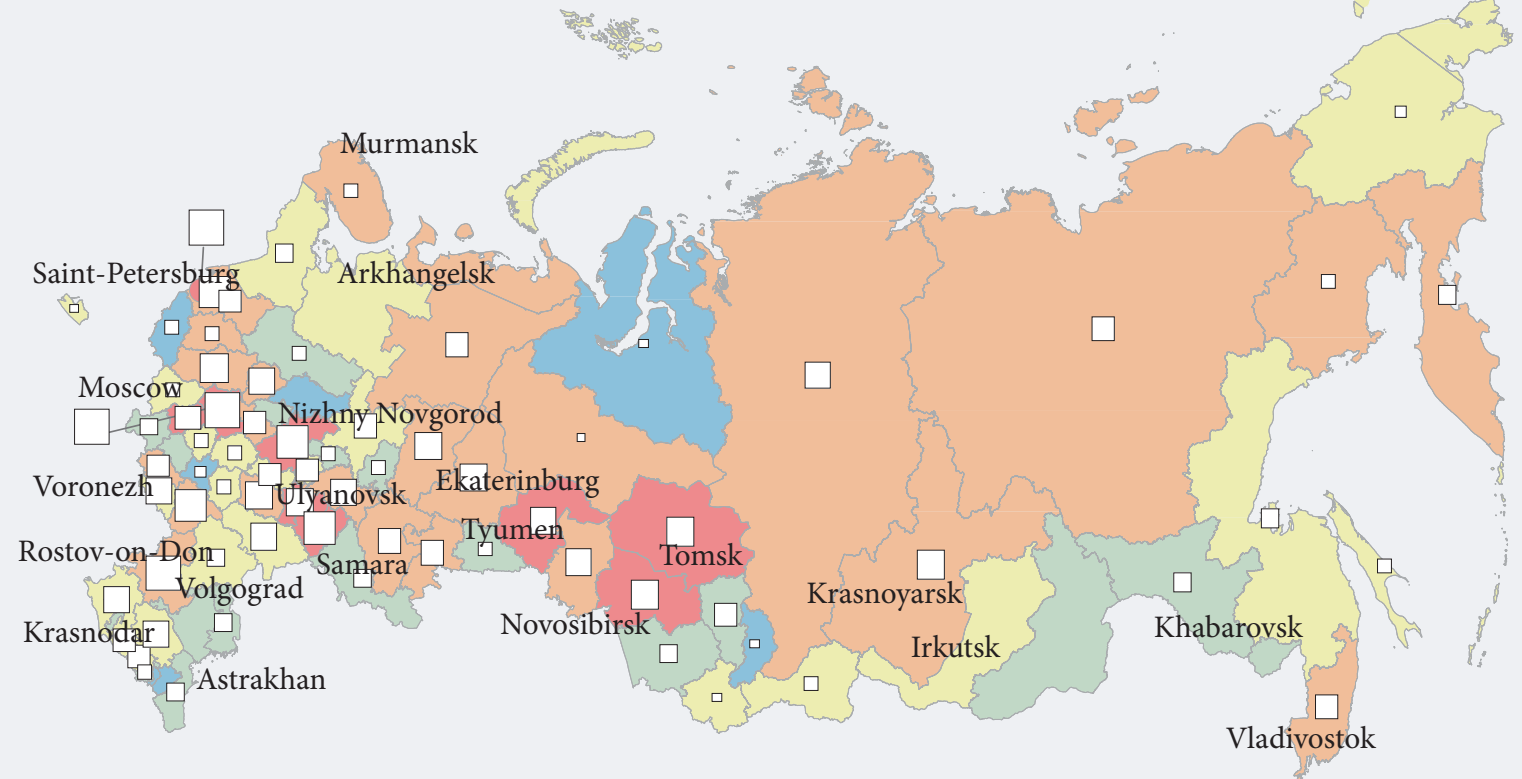

R\&D expenditures per economically active urban citizens (thousand rubles per capita)

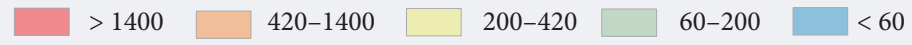

$\mathrm{R} \& \mathrm{D}$ expenditures on equipment (million rubles)

$\square>50 \quad \square \quad \begin{array}{llllllll} & 12-50 \quad \square & -5.5-12 \quad \square & 1.5-2 \quad \square & 0.2-1.5 \quad \square<0.2\end{array}$

Source: compiled by the authors.

\section{Figure 4. Number of economically active urban residents in Russian regions, 2012}

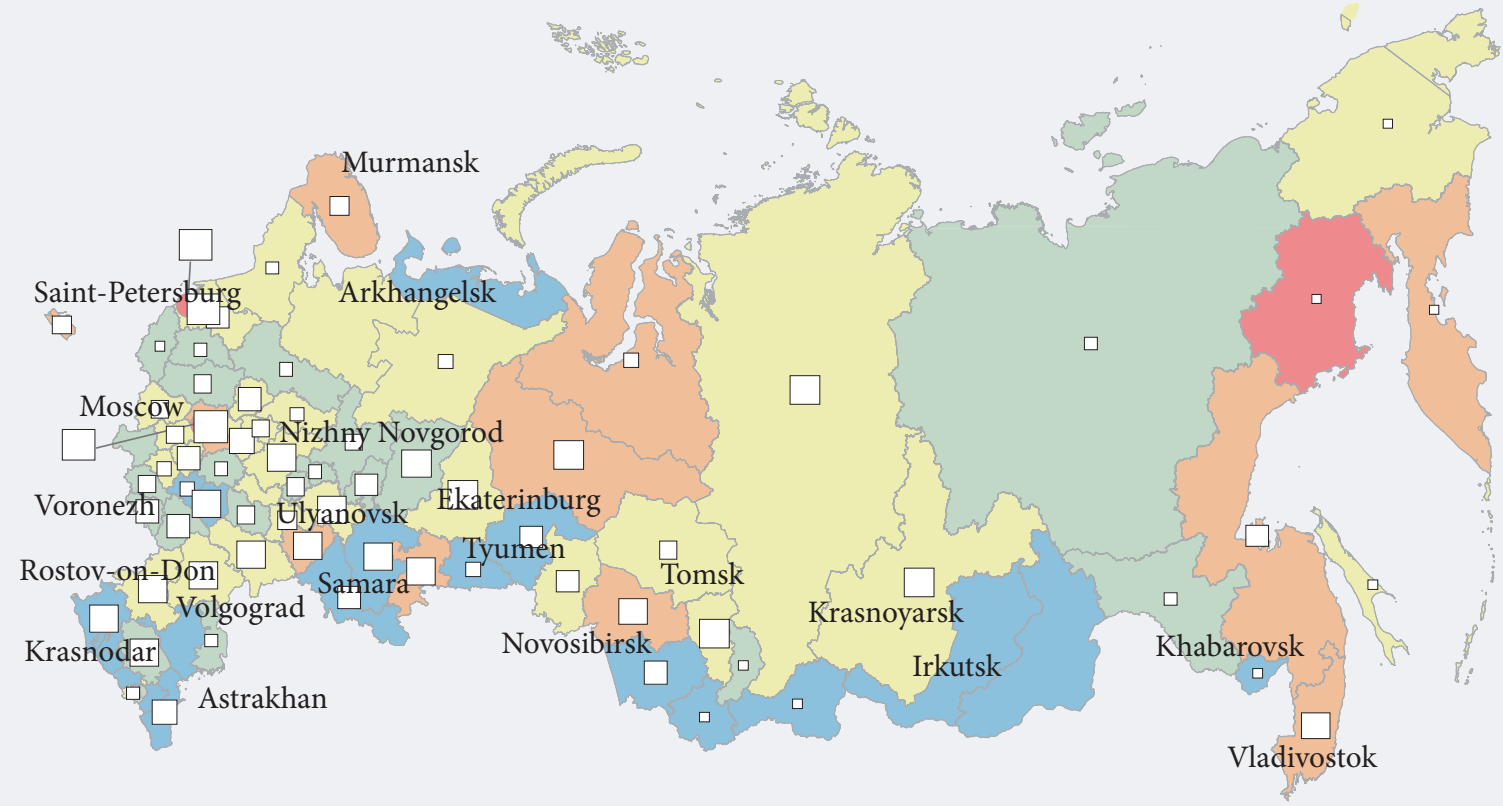

Share of economically active urban citizens with higher education (\%)

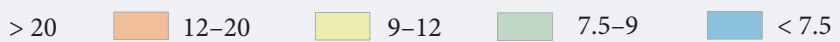

Number of economically active urban citizens with higher education (thousand people)

$\square>500 \quad \square$ 200-500 $\square 130-200 \quad \square 100-130 \quad \square 55-100 \quad \square<55$

Source: compiled by the authors. 
Where:

RnD_empl - number of R\&D staff of region $i$;

$R n D \_$empl $l_{j}$ - number of employees in regions $j$, located at a distance of $R_{i}{ }^{9}$;

$a$ - the coefficient of resistance from the environment (measures the extent to which the geographical distance reduces interactions among researchers).

We also assumed a known critical distance Dist ,rit, beyond which the interaction between researchers in two, statistically average regions $\left(M e a n\left(R N D \_e m p l\right)\right)$ becomes insignificant $(\delta$ - the threshold number of interactions below which the interaction is insignificant, e.g. one):

$$
\frac{\sqrt{\operatorname{Mean}\left(R n D_{-} \text {empl }_{i}\right) \cdot \operatorname{Mean}\left(\text { RnD_empl }_{j}\right)}}{\text { Dist }_{\text {crit }}^{\alpha}} \leq \delta ; \alpha \geq \frac{\log \left(\frac{\operatorname{Mean}\left(\text { RnD_empl }_{i}\right)}{\delta}\right)}{\log \left(\text { Dist }_{\text {crit }}\right)}
$$

Based on existing studies on knowledge spillovers, we expect that researchers from two, statistically average regions situated $120 \mathrm{~km}^{10}$ apart cannot produce more than one interaction, while a for Russian regions is equal to:

$\log \left(\frac{9774.36}{1}\right) / \log (120)=1.919067$.

The advantages of this indicator are its universality, straightforward nature, and positive experiences of using it in gravity models. As another measure of potential inter-regional knowledge spillovers, we also use the average level of patenting activity in neighbouring regions. To assess the impact of agglomeration effects, we used indicators of population density and the share of the urban population.

We employed a fixed effects model, and specified it to take account of the non-random sample. We also ran the F, LM, and Hausman tests to specify the model in each of the cases studied. The test model took the form:

$$
\ln \left(\text { Innov }_{i, t}\right)=\alpha+\beta_{1} \times \ln \left(\text { Rnd_any }_{i, t}\right)+\beta_{2} \times \ln \left(\text { Hum_Cap }_{i, t}\right)+\beta_{3} \times \ln \left(\text { Agglom }_{i, t}\right)+\beta_{4} \times \ln \left(\text { KSpill }_{i, t}\right)+\varepsilon_{i, t}
$$

Where:

$i$ - region of Russia in time $t$;

Rnd_any - all types of R\&D expenditures;

Hum_Cap - indicators of human capital;

KSpill - measures of potential knowledge spillovers;

Agglom - indicators of potential agglomeration effects.

Because all the above factors were expressed by several variables, we carried out thorough checks to detect possible multicollinearity using the coefficient of increased dispersion and pair-wise correlation matrices.

\section{Table 3. Innovation production (Innov) in regions of Russia by number of potentially commercializable patents}

\begin{tabular}{|l|l|}
\hline Leading regions for innovation production & $\begin{array}{l}\text { Moscow }(1119) \\
\text { St Petersurg (306.4) } \\
\text { Moscow region (231) }\end{array}$ \\
\hline 'Outsider' regions for innovation production & $\begin{array}{l}\text { Pskov region }(8.1) \\
\text { Novgorod region (7.1) } \\
\text { Zabaikal krai (4.1) }\end{array}$ \\
\hline Mean & 47.17 ( Krasnoyarsk krai) \\
\hline Median & $21.25(\sim$ Kursk region) \\
\hline Standard deviation & 114.58 \\
\hline Asymmetry & 7.17 \\
\hline Skewness (peaked or flat nature of data relative to a normal distribution) & 59.19 \\
\hline Coefficient of variation & 2.42 \\
\hline Coefficient of variation & 0.84 \\
\hline Source: compiled by the authors. & \\
\hline
\end{tabular}

\footnotetext{
${ }^{9}$ We measured the distance by the length of railway tracks between the regional capital cities. Where there was no railway line, we used the length of highways, and occasionally we used the length of rivers.

${ }^{10}$ The numbers of joint patents, articles, and patent citations decreases quite quickly with increasing geographical distance. [Jaffe et al., 1992; Adams, Jaffe, 2002; Adams et al., 2005; Maurseth, Verspagen, 2002; Belenzon et al., 2013] show that beyond 120150 miles (approx. 190-240km), researchers practically never cite each other's patents (although these are average distances), which means that they are neither in practice nor virtually collaborating. In Russia, we argue that the critical distance for interregional knowledge spillovers is lower because of lesser mobility and the closed (inward) nature of the various scientific schools.
} 


\section{Table 4. Regression results from fixed effects model 1 (dependent variable:} number of potentially commercializable patents)

\begin{tabular}{|c|c|c|c|c|c|c|}
\hline & \multicolumn{6}{|c|}{ Model } \\
\hline & 1 & 2 & 3 & 4 & 5 & 6 \\
\hline Constant & $\begin{array}{l}0.23 \\
(0.26)\end{array}$ & $\begin{array}{l}0.17 \\
(0.24)\end{array}$ & $\begin{array}{l}0.31 \\
(0.24)\end{array}$ & $\begin{array}{l}0.60^{* *} \\
(0.24)\end{array}$ & $\begin{array}{l}0.05 \\
(0.24)\end{array}$ & $\begin{array}{c}0.34 \\
(0.24)\end{array}$ \\
\hline $\begin{array}{l}\text { Number of economically active urban } \\
\text { population with a higher education }\end{array}$ & $\begin{array}{c}0.56^{* * *} \\
(0.05)\end{array}$ & $\begin{array}{c}0.53^{* * *} \\
(0.05)\end{array}$ & $\begin{array}{l}0.49^{* * *} \\
(0.05)\end{array}$ & $\begin{array}{l}0.39 * * * \\
(0.06)\end{array}$ & $\begin{array}{c}0.34^{* * *} \\
(0.06)\end{array}$ & $\begin{array}{c}0.29^{* * *} \\
(0.06)\end{array}$ \\
\hline $\begin{array}{l}\text { Real internal spending on purchase of } \\
\text { equipment }\end{array}$ & $\begin{array}{c}0.06^{* * *} \\
(0.01)\end{array}$ & - & $\begin{array}{l}0.05^{\star * *} \\
(0.01)\end{array}$ & $\begin{array}{c}0.05^{\star * *} \\
(0.01)\end{array}$ & $\begin{array}{c}0.04^{* * *} \\
(0.01)\end{array}$ & $\begin{array}{c}0.05^{* * *} \\
(0.01) \\
\end{array}$ \\
\hline Real internal spending on basic research & - & $\begin{array}{l}0.05^{\star * *} \\
(0.01)\end{array}$ & $\begin{array}{l}0.05^{\star * *} \\
(0.01)\end{array}$ & $\begin{array}{l}0.04^{\star * *} \\
(0.01)\end{array}$ & $\begin{array}{c}0.03^{* * *} \\
(0.01)\end{array}$ & $\begin{array}{c}0.04^{* * *} \\
(0.01)\end{array}$ \\
\hline Real internal spending on applied research & - & $\begin{array}{c}0.03^{* * *} \\
(0.01)\end{array}$ & $\begin{array}{l}0.02^{* *} \\
(0.01)\end{array}$ & $\begin{array}{l}0.02^{* *} \\
(0.01)\end{array}$ & $\begin{array}{l}0.02^{*} \\
(0.01)\end{array}$ & $\begin{array}{c}0.01 \\
(0.01)\end{array}$ \\
\hline Potential for interactions between researchers & - & - & - & $\begin{array}{c}-0.36^{* * *} \\
(0.08)\end{array}$ & - & $\begin{array}{l}-0.27^{* * *} \\
(0.07)\end{array}$ \\
\hline $\begin{array}{l}\text { Average patenting level in neighbouring } \\
\text { regions }\end{array}$ & - & - & - & - & $\begin{array}{c}0.32^{* * *} \\
(0.05)\end{array}$ & $\begin{array}{c}0.27^{* * *} \\
(0.05)\end{array}$ \\
\hline LSDV R $^{2}$ & 0.95 & 0.95 & 0.95 & 0.95 & 0.95 & 0.95 \\
\hline Akaike's Information Criterion (AIC) & 462.86 & 459.39 & 437.72 & 417.71 & 398.30 & 316.06 \\
\hline Schwarz's Bayesian Criterion (BIC) & 796.34 & 796.49 & 779.08 & 763.88 & 738.56 & 655.27 \\
\hline \multicolumn{5}{|c|}{ F-test for model specification. Null hypothesis: Pool versus FE (p-value) } & \multicolumn{2}{|c|}{$\begin{array}{l}35.36 \\
(0.00)\end{array}$} \\
\hline \multicolumn{5}{|c|}{ LM-criteria for model specification. Null hypothesis: Pool versus RE: Pool (p-value) } & \multicolumn{2}{|c|}{$\begin{array}{c}1843.61 \\
(0.00)\end{array}$} \\
\hline \multicolumn{5}{|c|}{ Hausman criteria for model specification. Null hypothesis: RE versus FE (p-value) } & \multicolumn{2}{|c|}{$\begin{array}{l}80.29 \\
(0.00)\end{array}$} \\
\hline \multicolumn{5}{|c|}{$\begin{array}{l}\text { Wald test for heteroskedasticity. Null hypothesis: observations have general dispersion of mistake } \\
\text { (p-value) }\end{array}$} & \multicolumn{2}{|c|}{$\begin{array}{c}6169.38 \\
(0.00)\end{array}$} \\
\hline \multicolumn{5}{|c|}{ Test for normal distribution of errors. Null hypothesis: errors are normally distributed (p-value) } & \multicolumn{2}{|c|}{$\begin{array}{c}958.72 \\
(0.00)\end{array}$} \\
\hline \multicolumn{7}{|c|}{$\begin{array}{l}\text { Note: As a result of the evaluation, we rejected the standard hypotheses about the nature of residual distribution in regressions. As the p-values show fror } \\
\text { the Wald test to check for heteroskedasticity and normality tests, there is non-uniform distribution in the model, and no Gaussian distribution. This shoul } \\
\text { be considered when interpreting the results given the specificities of the sample (the presence of outliers). Significance of the coefficients in the regression } \\
\star-10 \% \text {; }{ }^{*}-5 \% \text {; } * * *-1 \% \text {. Standard errors in brackets. Number of observations: } 67 \mathrm{i}^{\star} 15 \mathrm{t}=1005 \text {. } \\
\text { Source: compiled by the authors. }\end{array}$} \\
\hline
\end{tabular}

\section{Results and discussion}

\section{Evaluating the factors of regional innovation}

In our first model, the dependent variable is an indicator of the number of potentially commercializable patents. This indicator can also be described as innovation production as all commercialized patents will eventually be made into new products. ${ }^{11}$ The primary rationale for using absolute values in the model is the concentration of production and employment in the regional capital cities of Russia [Perret, 2014].

The sample is quite diverse in terms of the absolute values of patents (Table 3). We see a big difference between the 'leading regions' of the cities of Moscow and St Petersburg, with their large concentrations of human capital and R\&D funding, and the other regions. However, when we exclude Moscow and St Petersburg, the coefficient of variation decreases significantly. The particularities of the sample mean we need to carefully check for heteroskedasticity and construct scatter plots.

We then ran several models to test our hypotheses. Table 4 gives the final results of the regressions. All variables were logged according to the KPF and dependencies. Figure 5 shows the scatter plots of the key dependencies.

We find that the factor most positively and significantly associated with innovative production is human capital, which we operationalize as the number of economically active urban population with a higher education $\left(H C_{-} u r b\right)$. Other significant variables with positive effects are real internal spending on the purchase of equipment, and basic and applied research. Moreover, the purchase of equipment is the most important factor for innovation production, which testifies to the highly degraded state of equipment in research institutes and laboratories and to their need for upgrading.The insignificance of developmental R\&D expenditures $\left(R n D \_d e v\right)$ in contrast to the significance of spending on basic (RnD_basic) and applied research (RnD_appl) may indicate their low effectiveness in Russia and, consequently, the low returns on investment. However, this result may also be explained by the fact that patents are not the main way of registering the results of $R \& D$.

\footnotetext{
${ }^{11}$ Many commercialized patents do not have commodification potential and are far from centres of innovation production. For the 'leading patenting regions', the chance of converting patents into innovative products is in this regard higher because of their relatively large scale and well-developed innovation systems.
} 
Figure 5. Scatter plots showing the dependence of innovation production ( $l \_$Innov) on determinants $(A, B, C)$

\section{A - expenditures on acquisition of equipment} (l_Rnd_infra)

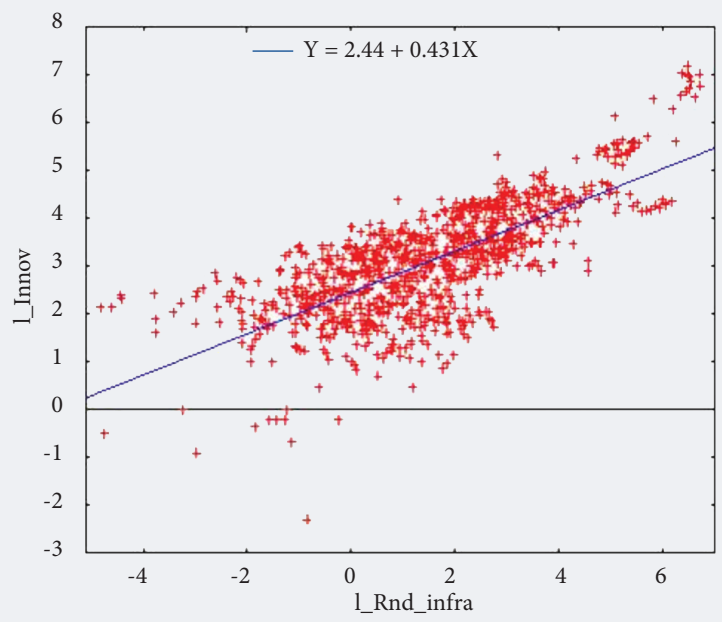

$B$ - average patenting levels in neighbouring regions ( $l$ _Neigh_innov)

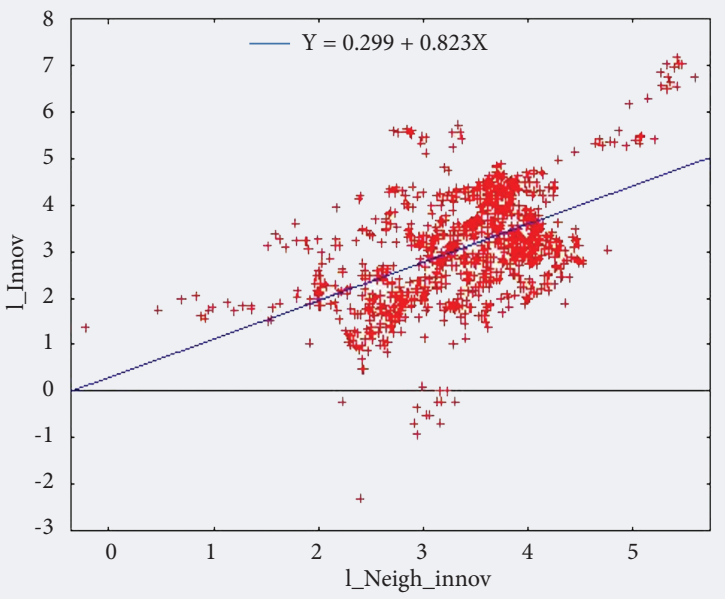

$\mathrm{C}$ - number of economically active urban residents with higher education $\left(\boldsymbol{l} \_H C \_u r b\right)$

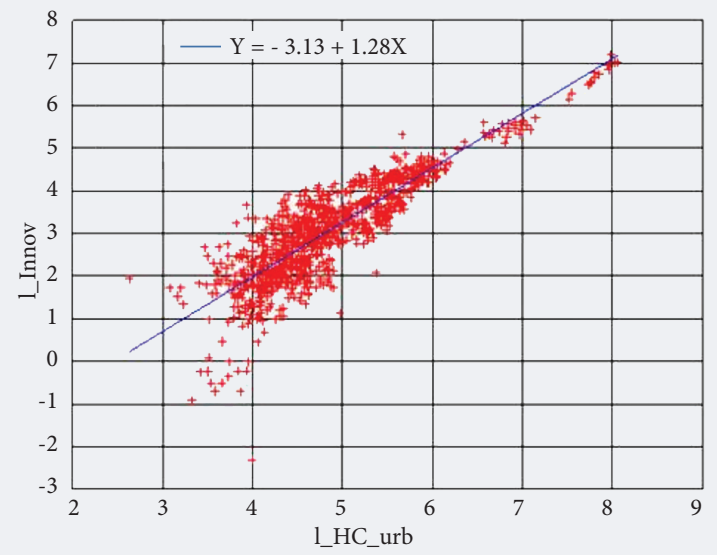

Source: compiled by the authors.
Our analysis found an unexpectedly significant and negative coefficient $(-0.36$ and -0.27 in columns 4 and 6 of Table 1 respectively, both significant at a 99\% confidence level) for the inter-regional knowledge spillovers factor, expressed in terms of the interaction potential of researchers (Pat potential). In other words, a one-unit increase in the potential for interactions between researchers had a small but very statistically significant, negative average effect on the number of potentially commercializable patents after controlling for fixed effects. This result contradicts our third hypothesis (H3) about the positive influence of inter-regional knowledge spillovers from neighbouring regions on innovation. Using the average patenting level in neighbouring regions as an indicator of knowledge transfer may lead to the opposite conclusion, which is evidence of the distribution of knowledge and trends to equal out the level of technological development. Russia's innovation system is characterized by a strong centre-periphery structure (Figure 3), which means that knowledge and highly skilled researchers tend to cluster in the "leader regions' that have high scientific-technical potential and a developed innovation ecosystem. Thus, proximity of 'donor' regions to the innovative core areas has a negative effect on the levels of innovation in the former. Yet at the same time, given the fewer limitations on knowledge spillovers in the form of patents, proximity to the 'centre' can become a positive factor.

In line with our expectations, population density and the share of urban population did not have any effects in our model. This is consistent with the assumption about high concentrations of human capital and fixed assets in the regional capital cities (estimates of these models not given). Figure 6 shows a scatter plot of real and imputed indicators of regions' innovation activity.

We conclude that our model one is quite good at characterizing patenting outputs in regions of Russia between 1998 and 2011.

\section{Evaluating the factors and the dynamics of regional innovation of economically active urban citizens}

Our dependent variable here is the number of potentially commercializable patents in the region (Innov) per economically active urban citizen to understand what determines innovation activity of urban residents (Figure 4; Table 5).

We found that human capital - operationalized as the share of employed with higher education - had a large and statistically significant effect on innovation in regions. People who have graduated from a higher education institution and who thus have the necessary skills, are more likely to create innovative technologies or processes. Spending on basic and applied R\&D also had small, positive, and statistically significant effects, as in the previous model (Table 4). Surprisingly, spending on researchers' salaries per economically active urban citizen was not statistically significant, although we expected this to stimulate the most likely innovators (researchers) to apply for patents. This may indicate the ineffectiveness of Russia's system of researchers' salaries, or that Russian researchers are not incentivized to apply for patents in light of the cumbersome application procedure.

We observe a negative correlation between average geometrical growth rates of innovation in regions now and in 1998 (Figure 7). Overall, Russian regions tend to show a convergence of rates of innovation activity. This finding contradicts several other studies [for example, Baburin, Zemtsov, 2013], which found that innovation tended to concentrated in a handful of regions and that patenting was polarized. We should point out that the dependence was relatively weak in our model $\left(\mathrm{R}^{2}\right.$ of approx. 0.5$)$, and hence 


\section{Figure 6. Real and predicted values of patent activity in regions of Russia}

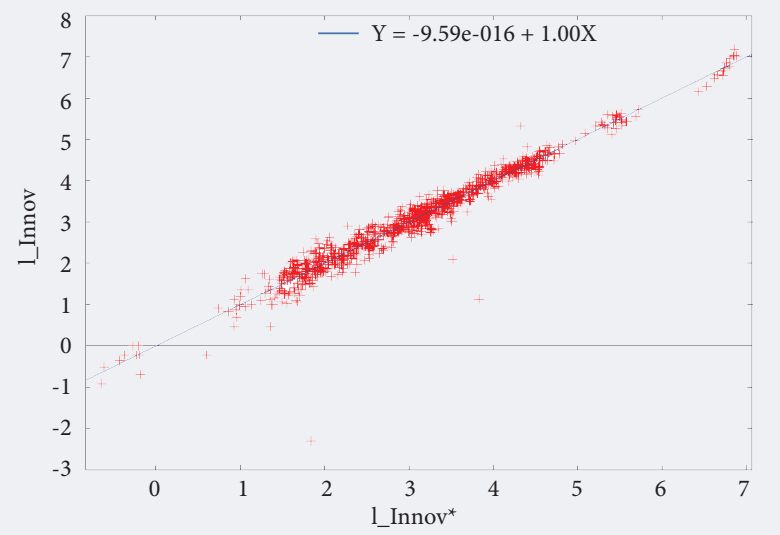

Source: compiled by the authors.

\section{Figure 7. Convergence in innovation activity in regions of Russia}

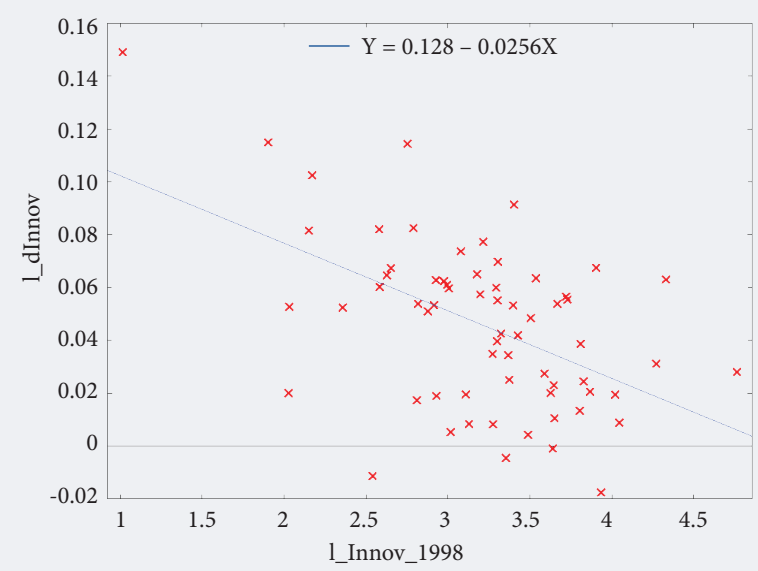

Source: compiled by the authors.

our finding about regional convergence is rather tenuous.

In relation to the unstable coefficient estimates over time that we identified above, we are particularly interested in the dynamics of the effects of human and physical capital. We can investigate this using the model of Mankiw-Romer-Weil [Mankiw et al., 1992]:

$$
\ln \left(\frac{\text { Innov }}{E A U}\right)=A+\frac{\alpha}{1-\alpha-\beta} \ln \left(H_{i g h} \text { empl }\right)+\frac{\beta}{1-\alpha-\beta} \ln \left(\frac{R n D_{-} \inf r a}{E A U}\right)-\frac{\alpha+\beta}{1-\alpha-\beta} \ln (n)+\varepsilon,
$$

Where:

$E A U$ - economically active urban population (EAU);

Table 5. Results of regressions (fixed effects model 2) (dependent variable: number of potentially commercializable patents per economically active urban citizen)

\begin{tabular}{|c|c|c|c|}
\hline Regression equalization & 1 & 2 & 3 \\
\hline Constant & $\begin{array}{l}1.86^{* *} \\
(0.16)\end{array}$ & $\begin{array}{l}1.77^{* * *} \\
(0.16)\end{array}$ & $\begin{array}{l}1.79^{* *} \\
(0.16)\end{array}$ \\
\hline Share of employed with higher education & $\begin{array}{c}0.51^{\star * *} \\
(0.06)\end{array}$ & $\begin{array}{l}0.48^{* * *} \\
(0.06)\end{array}$ & $\begin{array}{c}0.45^{\star * *} \\
(0.06)\end{array}$ \\
\hline Real internal spending on acquisition of equipment per economically active urban citizen & $\begin{array}{l}0.06^{\star * *} \\
(0.01)\end{array}$ & - & $\begin{array}{c}0.05^{\star * *} \\
(0.01)\end{array}$ \\
\hline Real internal spending on basic research per economically active urban citizen & - & $\begin{array}{c}0.05^{* * *} \\
(0.01)\end{array}$ & $\begin{array}{c}0.05^{* * *} \\
(0.01)\end{array}$ \\
\hline Real internal spending on applied research per economically active urban citizen & - & $\begin{array}{l}0.03^{* * *} \\
(0.01)\end{array}$ & $\begin{array}{l}0.03^{* *} \\
(0.01)\end{array}$ \\
\hline LSDV R $^{2}$ & 0.84 & 0.85 & 0.85 \\
\hline Akaike's Information Criterion (AIC) & 459.21 & 451.06 & 433.10 \\
\hline Schwarz's Bayesian Criterion (BIC) & 792.47 & 788.15 & 774.23 \\
\hline \multicolumn{3}{|l|}{ F-test for model specification. Null hypothesis: Pool versus FE (p-value) } & $\begin{array}{l}42.10 \\
(0.00)\end{array}$ \\
\hline \multicolumn{3}{|l|}{ LM-criteria for model specification. Null hypothesis: Pool versus RE: Pool (p-value) } & $\begin{array}{c}2805.04 \\
(0.00)\end{array}$ \\
\hline \multicolumn{3}{|l|}{ Hausman criteria for model specification. Null hypothesis: RE versus FE (p-value) } & $\begin{array}{l}25.78 \\
(0.00) \\
\end{array}$ \\
\hline \multicolumn{3}{|l|}{ Wald test for heteroskedasticity. Null hypothesis: observations have general error dispersion (p-value) } & $\begin{array}{c}4989.95 \\
(0.00)\end{array}$ \\
\hline \multicolumn{3}{|l|}{ Test for normal distribution of errors. Null hypothesis: errors are normally distributed (p-value) } & $\begin{array}{c}581.95 \\
(0.00)\end{array}$ \\
\hline \multicolumn{4}{|c|}{$\begin{array}{l}\text { Note: Checks for the influence of regional structures and temporary dynamics showed that the model accurately and effectively assesses the differences between } \\
\text { regions, although only weakly takes temporary effects into account. The distribution over time is the same and normal for every region. A consequence of thi } \\
\text { is that when evaluating the between models, we can expect the standard suppositions about the distribution of residuals of the regression. Significance of the } \\
\text { coefficients in the regressions: }{ }^{*}-10 \% ;{ }^{* *}-5 \% ;{ }^{* * *}-1 \% \text {. Standard errors in brackets. Number of observations: } 67 \mathrm{i}^{\star} 15 \mathrm{t}=1005 \text {. }\end{array}$} \\
\hline \multicolumn{4}{|l|}{ Source: compiled by the authors. } \\
\hline
\end{tabular}




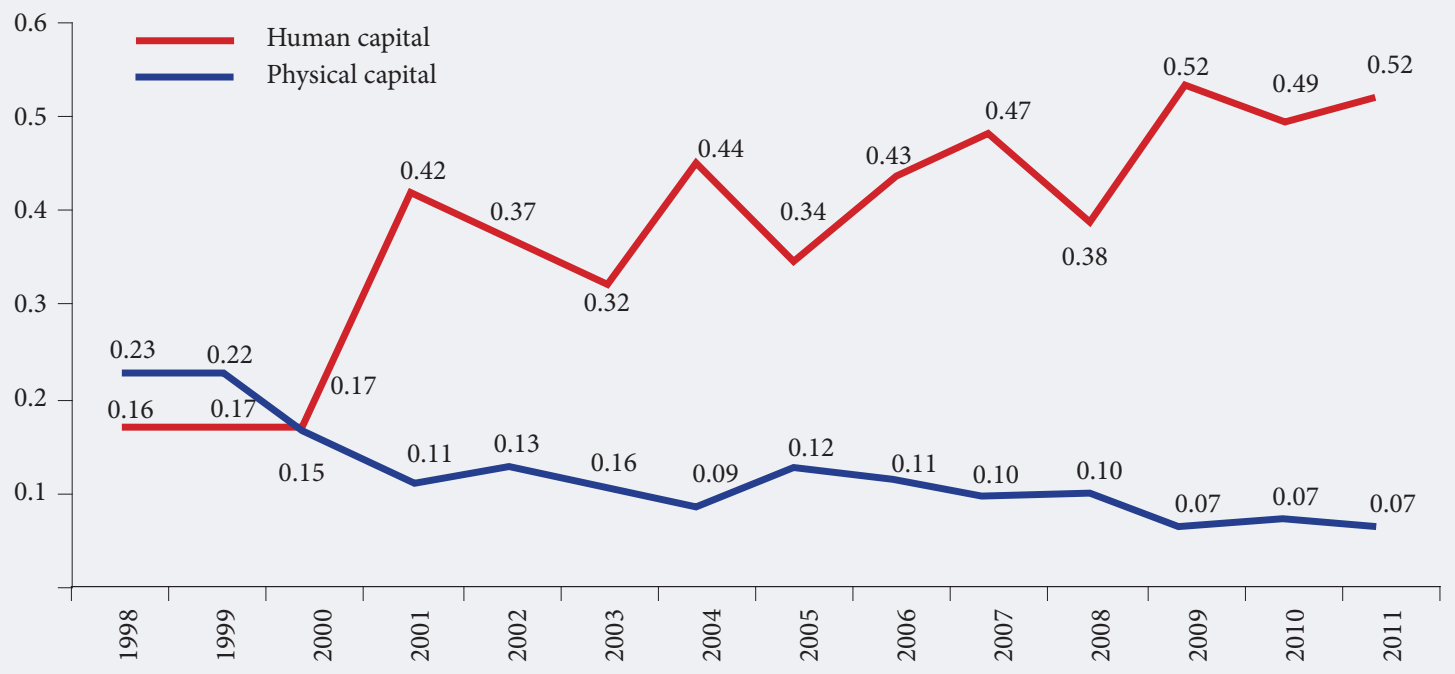

Source: compiled by the authors.

High_empl - the proportion of employees with a higher education;

Rnd_infra - spending on R\&D;

$n$ - the growth rate of the economically active urban population (EAU) in the region; ${ }^{12}$ $\alpha$ and $\beta-$ the elasticity of innovation output by human and physical capital respectively. A straightforward system of equalizations gives the following estimates for $\alpha$ and $\beta$ :

$$
\left\{\begin{array}{l}
\alpha=\frac{\theta_{1}}{1+\theta_{1}+\theta_{2}} \\
\beta=\frac{\theta_{2}}{1+\theta_{1}+\theta_{2}}
\end{array}\right.
$$

Where:

$\theta_{1}$ and $\theta_{2}$ - the resulting regression coefficients using the logged values of the share of employees with a higher education and R\&D spending per economically active urban resident (EAU), respectively.

We regressed the data for 14 years (1998-2011) using the ordinary least squares method to identify the dynamics per year (Figure 8).

From the start of the 2000s decade, we see that human capital has played an increasingly important role in innovation in Russia. In contrast, the role of physical capital (resources spent on equipment and materials for R\&D) has slowly declined in the same period. This either indicates the ineffectiveness of $R \& D$ funding or the low priority attached to patenting by R\&D expenditures. Moreover, in the first few years of this period, the role of spending on physical capital (equipment and R\&D materials purchases) was higher than that on human capital. Then over the 2000s decade, patenting activity was increasingly concentrated in regions with a high level of human capital in a context of growing importance of human capital for innovation in Russia. These findings complement the results of other studies modelling economic growth in Russian regions [Komarova, Pavshok, 2007; Komarova, Kritsyna, 2012].

\section{Conclusions}

The database we have collected on social and economic indicators for regions of Russia between 1998 and 2011 enabled us to evaluate the effectiveness of various kinds of R\&D spending and test our hypotheses. We were able to overcome data issues associated with the low quality of Russian patenting statistics and Russian patents themselves by developing a new indicator that incorporates both Russian and international patent applications. This indicator assesses the rate of commercialization of these patent applications. This new indicator enabled us to evaluate the real level of innovation performance as reliably as possible given the data limitations.

We argue that our indicator for human capital - the economically active urban population with higher education - is a substantial factor of innovation as it takes into account the significance of agglomeration

\footnotetext{
${ }^{12}$ In the classical model of Mankiw-Romer-Vale, the value $n$ presupposes growth in human capital as well as the writing-off of human and physical capital [Mankiw et al., 1992].
} 
effects. Our most significant finding here is that human capital is key for innovation, thus confirming Brenner and Broekel's hypotheses with empirical data from Russia. The economically active urban population with a higher education - the so-called 'creative class' or inhabitants of the 'first Russia' has the potential to become the foundation of innovative development and economic diversification in Russia. Moreover, we found that human capital has become an increasingly significant factor of Russian innovation activity over the 2000s.

The process of creating regional innovation systems is a lengthy and cumulative process. Much time is thus needed for such systems to take root and for human capital to produce maximum returns. Our econometric analyses showed that a $1 \%$ increase in the quality and quantity of human capital leads to an average rise of innovation output of $0.5 \%$. At the same time, a $1 \%$ increase of various kinds of R\&D spending leads only to a $0.05 \%$ growth in innovation. Thus, greater spending on R\&D in regions of Russia with weak human capital does not lead to a proportional increase in innovation.

This conclusion does not deny the fact that funding for various kinds of R\&D does affect innovation performance. We found that spending on basic R\&D (related to the most significant research in the Russian Academy of Sciences) and on acquiring new equipment (linked to the high rate of wear and tear of equipment in Russia) had the most positive and significant effects on innovation performance. Funding for researchers' salaries was insignificant. Although in contrast to much of economic theory, this result may suggest that the Russian system of researchers' salaries is ineffective. We found it hard to assess the effects of basic economic stimuli on R\&D productivity and further research on the effects of different kinds of R\&D funding is needed.

Our suggested new indicator for inter-regional knowledge spillovers - expressed by calculating the potential for researchers to interact - enables us to assess the importance of this factor for innovation in Russian regions. Our results confirm the presence of a strong centre-periphery structure of the Russian national innovation system [Baburin, Zemtsov, 2013]. Moreover, the observed 'brain drain' of researchers to more developed neighbouring regions leads to greater human capital in the largest scientific centres and contributes to a widening technological gap between the leading and 'donor' regions. Nevertheless, we do see a positive influence of patenting in neighbouring regions on innovation output in a given region. These two, seemingly contradictory, findings may be linked: consider the migratory nature of knowledge spillovers through which researchers go to the innovation leading regions, learn from them about advanced technologies, and then return to 'innovation lagging' regions and subsequently help to build up the technological potential of these regions. This trend could certainly be linked to various regional specializations, through which you witness the outflow of experts in one sector, and simultaneously the in-migration of other kinds of specialists who are more suitable for that region. This issue is ambiguous and merits further study.

Our paper confirms the conclusions of previous studies that in Russia, the market for innovation is insufficient, funding for innovation is ineffective, and the quality of registered applications of intellectual property (patents) remains low. Finding solutions to this situation may lie in creating favourable conditions for innovative entrepreneurship. It is also necessary to attract more private investment in $R \& D$ (including venture capital) alongside more effective state funding, and develop the market for intellectual property. As experiences in other countries beyond Russia have shown, these factors contribute to an innovation-friendly climate at the national level.

This study was implemented with the support of the National Research University Higher School of Economics' Basic Research Programme and the support of state subsidy funds allocated to support leading universities in the Russian Federation to increase their competitiveness among the leading global scientific research centres.

\section{References}

Acs Z.J., Braunerhjelm P., Audretsch D.B., Carlsson B. (2009) The knowledge spillover theory of entrepreneurship. Small Business Economics, vol. 32, no 1, pp. 15-30.

Adams J.D., Black G.C., Clemmons J.R., Stephan P.E. (2005) Scientific teams and institutional collaborations: Evidence from US universities, 1981-1999. Research Policy, vol. 34, no 3, pp. 259-285.

Adams J.D., Jaffe A.B. (2002) Bounding the effects of R\&D: An investigation using matched firm and establishment data. Rand Journal of Economics, vol. 27, pp. 700-721.

Arkhipova M., Karpov E. (2012) Analiz i modelirovanie patentnoi aktivnosti v Rossii i razvitykh stranakh mira [Analysis and modeling of patent activity in Russia and developed countries]. RISK: Resursy, Informatsiya, Snabzhenie, Konkurentsiya [RISK: Resources, Information, Supply, Competition], no 4, pp. 286-293 (in Russian).

Baburin V., Zemtsov S. (2013) Geografiya innovatsionnykh protsessov v Rossii [Geography of innovation processes in Russia]'. Vestnik Moskovskogo universiteta. Seriya 'Geografiya' [MSU Bulletin 'Geography, Environment, Sustainability'], no 5, pp. 25-32 (in Russian).

Barinova V., Mal'tseva A., Sorokina A., Eremkin V. (2014) Podkhody k otsenke effektivnosti funktsionirovaniya ob"ektov innovatsionnoi infrastruktury $\mathrm{v}$ Rossii [Approaches to assessing the adequacy and efficiency of the innovation infrastructure facilities in Russia]. Innovatsii [Innovations], no 3 (185), pp. 2-11 (in Russian).

Belenzon S., Schankerman M. (2013) Spreading the word: Geography, policy, and knowledge spillovers. Review of Economics and Statistics, vol. 95, no 3, pp. 884-903.

Bortnik I., Zinov V., Kotsyubinskii V., Sorokina A. (2013) Voprosy dostovernosti statisticheskoi informatsii ob innovatsionnoi deyatel'nosti v Rossii [Questions the Reliability of Statistical Information on Innovative Activities in Russia]. Innovatsii [Innovations], no 10 (180), pp. 10-17 (in Russian). 
Bottazzi L., Peri G. (2003) Innovation and spillovers in regions: Evidence from European patent data. European Economic Review, vol. 47, no 4, pp. 687-710.

Brenner T., Broekel T. (2009) Methodological issues in measuring innovation performance of spatial units. Industry and Innovation, vol. 18, no 1, pp. 7-37.

Crescenzi R., Jaax A. (2015) Innovation in Russia: The territorial dimension (Papers in Evolutionary Economic Geography no 1509), Utrecht: Utrecht University.

Dettmann E., Dominguez Lacasa I., Gunther J., Jindra B. (2014) Determinanty zarubezhnoi tekhnologicheskoi aktivnosti $\mathrm{v}$ Germanii: Kolichestvennyi analiz transnatsional'nykh patentov [Determinants of Foreign Technological Activity in German Regions - A Count Model Analysis of Transnational Patents]. Foresight-Russia, vol. 8, no 1, pp. 34-51 (in Russian).

Feldman M.P. (1999) The new economics of innovation, spillovers and agglomeration: A review of empirical studies. Economics of Innovation and New Technology, vol. 8, no 1-2, pp. 5-25.

Feldman M.P., Florida R. (1994) The geographic sources of innovation: Technological infrastructure and product innovation in the United States. Annals of the Association of American Geographers, vol. 84, no 2, pp. 210-229.

Florida R.L. (2002) The Rise of the Creative Class: And How It's Transforming Work, Leisure, Community and Everyday Life, New York: Basic Books.

Fritsch M., Franke G. (2003) Innovation, regional knowledge spillovers and R\&D cooperation. Research Policy, vol. 33, no 2, pp. 245-255.

Gokhberg L., Kuznetsova T. (2010) Novaya innovatsionnaya politika v kontekste modernizatsii ekonomiki [New Innovation Policy in the Context of Modernization of the Economy]. Zhurnal novoi ekonomicheskoi assotsiatsii [Journal of the New Economic Association], no 7, pp. 141-143 (in Russian).

Gokhberg L., Kuznetsova T. (2011) Strategiya-2020: novye kontury rossiiskoi innovatsionnoi politiki [Strategy 2020: New Outlines of Russian Innovation Policy]. Foresight-Russia, vol. 54, no 4, pp. 8-30 (in Russian).

Griliches Z. (1979) Issues in assessing the contribution of research and development to productivity growth. The Bell Journal of Economics, vol. 10, no 1, pp. 92-116.

Griliches Z. (1984) Introduction to "R\&D, Patents, and Productivity". R\&D, Patents, and Productivity (ed. Z. Griliches), National Bureau of Economic Research, University of Chicago, pp. 1-20.

Griliches Z. (ed.) (2007) R\&D, patents and productivity, Chicago: University of Chicago Press.

Hanson G.H. (2005) Market potential, increasing returns and geographic concentration. Journal of International Economics, vol. 67, no 1, pp. 1-24.

Head K., Mayer T. (2004) Market potential and the location of Japanese investment in the European Union. Review of Economics and Statistics, vol. 86, no 4, pp. 959-972.

HSE (2014) Nauka. Innovatsii. Informatsionnoe obshchestvo: 2014 (kratkii statisticheskii sbornik) [Science. Innovation. Information Society: 2014 (brief data book)], Moscow: HSE (in Russian).

Jaffe A.B. (1989) Real effects of academic research. The American Economic Review, vol. 79, no 5, pp. 957-970.

Jaffe A.B., Trajtenberg M., Henderson R. (1992) Geographic localization of knowledge spillovers as evidenced by patent citations, Cambridge, MA: National Bureau of Economic Research.

Komarova A., Kritsyna E. (2012) O vklade chelovecheskogo kapitala v rost VRP regionov Rossii [On the proportion of human capital in GRP of Russian Regions]. Vestnik NGU. Seriya 'Sotsial'no-ekonomicheskie nauki' [Vestnik NSU. Series: Social and Economics Sciences], vol. 12, no 3, pp. 5-14 (in Russian).

Komarova A., Pavshok O. (2007) Otsenka vklada chelovecheskogo kapitala v ekonomicheskii rost regionov Rossii (na osnove modeli Menk'yu-Romera-Ueila) [Evaluation of the contribution of human capital to economic growth in Russian regions (based on the model of Mankiw-Romer-Weil)]. Vestnik NGU. Seriya 'Sotsial'no-ekonomicheskie nauki' [Vestnik NSU. Series: Social and Economics Sciences], vol. 7, no 3, pp. 191-201 (in Russian).

Lei Z., Sun Z., Wright B. (2012) Patent subsidy and patent filing in China, Berkeley: UCLA.

Leslie T.F., O’hUallachain B. (2007) Rethinking the regional knowledge production function. Journal of Economic Geography, vol. 7, pp. 737-752.

Mankiw N.G., Romer D., Weil D.N. (1992) A Contribution to the Empirics of Economic Growth. The Quarterly Journal of Economics, vol. 107, no 2, pp. 407-437.

Mariev O., Savin I. (2010) Faktory innovatsionnoi aktivnosti rossiiskikh regionov: modelirovanie i empiricheskii analiz [Determinants of innovation performance of the Russian regions: modeling and empirical analysis]. Ekonomika regiona [Economics of Region], no 3, pp. 235-244 (in Russian).

Maurseth P.B., Verspagen B. (2002) Knowledge spillovers in Europe: A patent citations analysis. The Scandinavian Journal of Economics, vol. 104, no 4, pp. 531-545.

Meissner D. (2012) Ekonomicheskie effekty 'peretoka' rezul'tatov nauchno-tekhnicheskoy i innovatsionnoy deyatel'nosti [The Economic Impact of Spillovers from R\&D and Innovation]. Foresight-Russia, vol. 6, no 4, pp. 20-31 (in Russian).

NBK-group (2013) Patentnaya aktivnost': Rossiya vs SShA. Analiticheskoe issledovanie iz tsikla 'Indikatory innovatsionnogo razvitiya rossiiskoi ekonomiki' [Patent Activity: Russia vs USA. Analytical study, series 'Indicators of innovation development of the Russian economy'], Moscow: NBK-group (in Russian).

Perret J.K. (2014) Knowledge as a Driver of Regional Growth in the Russian Federation, Heidelberg: Springer.

Pilyasov A. (ed.) (2012) Sinergiya prostranstva: regional'nye innovatsionnye sistemy, klastery i peretoki znaniya [Synergy space: regional innovation systems, clusters, and the flows of knowledge], Smolensk: Oikumena (in Russian).

Polanyi M. (1966) The logic of tacit inference. Philosophy, vol. 41, no 155, pp. 1-18.

Romer P.M. (1986) Increasing returns and long-run growth. The Journal of Political Economy, vol. 94, no 5, pp. $1002-1037$.

Shtertser T.A. (2005) Empiricheskii analiz faktorov innovatsionnoi aktivnosti v sub"ektakh RF [Empirical analysis of the factors of innovation activity in the regions of Russia]. Vestnik NGU. Seriya 'Sotsial'no-ekonomicheskie nauki' [Vestnik NSU. Series: Social and Economics Sciences], vol. 5, no 2, pp. 100-109 (in Russian).

Suslov V. (ed.) (2007) Innovatsionnyi potentsial nauchnogo tsentra: Metodologicheskie i metodicheskie problemy analiza $i$ otsenki [Innovation capabilities of a research centre: Methodological and methodical problems of analysis and evaluation], Novosibirsk: IEIE (in Russian).

WIPO (2013) PCT Yearly Review 2013, Geneva: World Intellectual Property Organization.

Zubarevich N. (2010) Goroda kak tsentry modernizatsii ekonomiki i chelovecheskogo kapitala [Cities as centers of economic modernization and human capital]. Obshchestvennye nauki i sovremennost' [Social Sciences and Modernity], no 5, pp. 5-19 (in Russian).

Zubarevich N. (2013) Four Russias: Human Potential and Social Differentiation of Russian Regions and Cities. Russia 2025: Scenarios for the Russian Future (eds. M. Lipman, N. Petrov), London, New York: Palgrave McMillan, pp. 67-85. 